\title{
ANALISIS FAKTOR-FAKTOR YANG MEMPENGARUHI PERMINTAAN DAN ELASTISITAS HARGA KEDELAI DI JAWA TIMUR
}

\begin{abstract}
Cut Nurul Aidha
UniSadhuGuna Business School

cnaidhaz@gmail.com

Abstrak

Kedelai adalah salah satu tanaman polong-polongan yang menjadi bahan dasar banyak makanan dari Asia Timur.Kedelai merupakan bahan pangan yang penting bagi masyarakat Indonesia, dan kedelai merupakan tanaman pangan utama selain padi, ubi, dan jagung. Kedelai merupakan bahan baku makanan yang bergizi seperti tahu dan tempe Kontribusi ekonomi yang besar dari tempe juga didukung oleh faktor budaya. Tempe merupakan bagian dari budaya pangan Indonesia. Kedelai sebagai bahan baku yang banyak digunakan, namun produksi kedelai dalam negeri tidak mampu mecukupi kebutuhan konsumsi kedelai, sehingga yang dilakukan pemerintah adalah dengan impor kedelai. Permasalahan dari penelitian ini adalah fakor-faktor apa saja yang berpengaruh terhadap permintaan kedelai di Jawa Timur. Penelitian ini menggunakan data provinsi Jawa Timur, dengan pertimbangan bahwa Jawa Timur sebagai provinsi yang memberikan sumbangan produksi dalam negeri terbesar. Analisis ini mengguakan regresi linier berganda dimana variabel yang digunakan dalam penelitian ini adalah harga kedelai lokal, harga kedelai impor, jumlah penduduk dan perndapatan per kapita. Jenis data yang digunakan adalah data sekunder yaitu data yang diambil dari data yang dipublikasikan seperti dari BPS, Pusat Data dan Sistem Informasi Pertanian.
\end{abstract}

Kata Kunci: permintaan; kedelai; harga kedelai lokal; harga kedelai impor; jumlah penduduk; pendapatan per kapita; regresi

\section{Pendahuluan}

Kedelai adalah salah satu tanaman polong-polongan yang menjadi bahan dasar banyak makanan dari Asia Timur seperti kecap, tahu dan tempe. Berdasarkan peninggalan arkeologi, tanaman ini telah dibudidayakan sejak 3500 tahun yang lalu di Asia Timur. Orang Cina merupakan pengguna kacang kedelai sebagai makanan yang pertama. Tahun 1100 SM, kacang kedelai telah ditanam dibagian selatan tengah Cina, kemudian kedelai diperkenalkan di Jepang sekitar tahun $100 \mathrm{M}$ dan meluas keseluruh negara-negara Asia secara pesat. Kacang kedelai dikenalkan di Eropa sekitar tahun 1500 M. Pada awal abad ke-18, kacang kedelai telah ditanam di Amerika Serikat. Kedelai putih diperkenalkan ke Nusantara oleh pendatang dari Cina. Kedelai merupakan sumber utama protein nabati dan minyak nabati dunia. Kedelai (Glycine max) sudah dibudidayakan sejak 1500 tahun SM dan baru masuk Indonesia, terutama Jawa sekitar tahun 1750. Kedelai paling baik ditanam di ladang dan persawahan antara musim kemarau dan musim hujan. 
Menurut Romburgh (1892) seperti dikutip oleh Manwan dan Sumarno (1996). Kedelai telah menjadi tanaman pangan penting di samping padi, jagung, ubi kayu dan ubi jalar, serta merupakan bagian usaha pertanian yang mantap di Pulau Jawa pada penghujung abad ke-19. Berdasarkan catatan dan laporan yang ada, informasi perkembangan penanaman kedelai di Indonesia baru dapat diikuti mulai tahun 1998 dimana tercatat luas areal panen sebesar 158.900 hektar. Menyadari bahwa kedelai merupakan bahan pangan yang penting bagi masyarakat Indonesia, perluasan areal panen dan peningkatan produksi nasional dimasukkan ke dalam program pembangunan semesta pada tahun 1962. Untuk merealisasikan program tersebut, Rapat Kedelai Nasional dilaksanakan di Bogor pada bulan September 1964 merumuskan beberapa petunjuk bagi program pengembangan kedelai di Indonesia yang meliputi perluasan areal panen dan intensifikasi produksi (Hadipurnomo, 2000).

Masalah kurangnya produksi kedelai nasional untuk mencukupi permintaan dalam negeri telah dimulai sejak tahun 1928 dimana pada tahun itu impor kedelai mulai dilakukan dan terus meningkat dari tahun ke tahun. Akibat resesi ekonomi tahun 1934, impor kedelai dilarang dan perlu diimbangi dengan upaya peningkatan produksi dalam negeri melalui perluasan areal panen. Ketergantungan terhadap kedelai impor tidak hanya disebabkan oleh jumlah produksi kedelai lokal yang tidak mencukupi kebutuhan masyarakat, tapi juga dikarenakan kualitas kedelai impor yang lebih bagus.

Data BPS menunjukan laju konsumsi kedelai, yang 60 persennya diolah menjadi tempe, melebihi laju pertumbuhan penduduk. Rata-rata laju pertumbuhan penduduk Indonesia tahun 1978-2008 adalah 1,56 per tahun, sedangkan data laju pertumbuhan konsumsi kedelai tahun 1978-2008 adalah 7,22 persen per tahun. (republika.com)

Visi dan Misi Joko Widodo-Jusuf Kalla dengan tema "Jalan Perubahan Untuk Indonesia Yang Berdaulat, Mandiri, dan Berkepribadian" yang disesuaikan dengan Rencana Pembangunan Jangka Panjang Nasional (RPJPN). Kedaulatan Pangan adalah konsep pemenuhan pangan melalui produksi lokal. Kedaulatan pangan merupakan konsep pemenuhan hak atas pangan yang berkualitas gizi baik dan sesuai secara budaya, diproduksi dengan sistem pertanian yang berkelanjutan dan ramah lingkungan

Tingginya permintaan kedelai dalam negeri menyebabkan impor kedelai tetap berlangsung dalam jumlah yang besar, bukan saja disebabkan karena pertambahan jumlah penduduk dan penurunan luas areal tanam, tetap juga akibat meningkatnya pendapatan masyarakat, serta berkembangnya industri makanan dan pakan yang menggunakan bahan baku kedelai (Damardjati et al., 2005).

Di Jatim, kebutuhan kedelai masyarakat 420 ribu ton tiap tahun, sementara produksi kedelai mencapai 366.999 ribu ton. Sementara produksi kedelai secara nasional mencapai 700-800 ribu ton per tahun, kebutuhannya sekira 2,25 juta ton. "Ini yang masih kurang. Meskipun kita menyumbang 43 persen produksi kedelai secara nasional. Tapi kedelai kami justru sampai sekarang belum pernah surplus," aku Kepala Dinas Pertanian Jatim, Wibowo Eko Putro.

Kendala yang dihadapi oleh para petani adalah tidak adanya jaminan harga yang diberikan oleh pemerintah ketika masa panen tiba. Yang terjadi pada petani kedelai 
adalah ketika panen tiba, harga kedelai anjlok sehingga petani enggan untuk menanam kedelai dan lebih memilih untuk menananm jenis tanaman pangan lain yang lebih menguntungkan. (lensaindonesia.com)

Pada tahun 2006-2008 terjadi penuruanan luas panen (Ha), dari 246.534 ha, 199.493 ha, kemudian 216.828 ha. Begitu juga dengan produktivitas dan juga produksinya mengalami penurunan. Untuk tahun 2009, dengan jumlah luas panen (ha) paling besar jumlahnya yaitu 264.779 ha, dengan produktivitas 13,42\% dan jumlah produksinya 355.260,00 ton. Dan pada tahun 2010 dengan luas panen 246.894 ha mampu memproduksi 339.491,00ton dengan produktivitas 13,75\%. Dan tahun 2011, terjadi peningkatan lahan yaitu menjadi 252.815 dengan produktivitas yang meningkat menjadi 14,52\% dengan produksi 366.999,00 ton. Dan untuk 20012 dan 2013 terjadi penurunan luas panen yaitu 220.815 ha dan 210.618 ha, dan produktivitas yang meningkat cukup baik yaitu $16,39 \%$ dan $15,64 \%$ dengan produksi 361.986 ton dan juga 329.461 ton.

Jawa Timur sebagai provinsi penyumbang 43\% kontribusi kedelai nasional, dengan jumlah penduduk 38.363.200 jiwa pada tahun 2013. Maka Jawa Timur dipilih sebagai provinsi yang diteliti dalam penelitian ini.

Berdasarkan keterangan di atas, terjadi ketidakseimbangan antara produksi dan permintaan kedelai. Oleh karena itu, peneliti ingin menganalisis faktor-faktor yang mempengaruhi permintaan kedelai di Jawa Timur dan juga elastisitas dari kedelai.

\section{Metode Penelitian}

1. Analisis Regresi Linier Berganda

Penelitian ini dilakukan untuk mengetahui pengaruh tingkat pendapatan per kapita dan jumlah penduduk terhadap tingkat permintaan kedelai di Jawa Timur. Teknik analisis data yang digunakan adalah teknik analisis kuantitatif yaitu regresi linier berganda. Model regresi linear berganda untuk penelitian ini ditunjukkan oleh persamaan sebagai berikut:

$$
y=a+b 1 x 1+b 2 x 2+e
$$

Keterangan:

$\mathrm{y}=$ Permintaan Kedelai $(\mathrm{kg})$

$\mathrm{a}=$ Konstanta

b1 = Koefisien regresi Pendapatan Per Kapita

$\mathrm{x} 1$ = Pendapatan Per Kapita

b2 = Koefisien regresi Jumlah Penduduk

$\mathrm{x} 2$ = Jumlah Penduduk

$\mathrm{e}=$ error

\section{Uji Statistik}

Pada pengujian hipotesis dilakukan beberapa uji, diantaranya adalah uji F. Uji $\mathrm{F}$ atau uji simultan yang digunakan untuk mengetahui pengaruh secara simultan dari 
variabel bebas terhadap variabel terikat. Uji t atau uji regresi parsial yang digunakan untuk mengetahui pengaruh masing masing variabel bebas terhadap variabel terikat.

3. Lokasi, Jenis dan Metode Pengumpulan Data

Penelitian ini difokuskan di Provinsi Jawa Timur, dengan periode observasi dari tahun 2003-2013. Metode penelitian ini menggunakan metode analisis deskriptif yang berupa data-data dimana dikumpulkan dan dikelompokan kemudian dianalisis dan di interpretasikan secara objektif. Penelitian ini menggunakan data time series dalam kurun waktu 14 tahun, tahun 2000- 2013 Data bersumber dari Badan Pusat Statistik (BPS), dan Departemen Pertanian. Data yng dikumpulkan terdiri dari jumlah permintaan kedelai, harga kedelai lokal, harga kedelai impor, jumlah penduduk dan pendapatan perkapita.

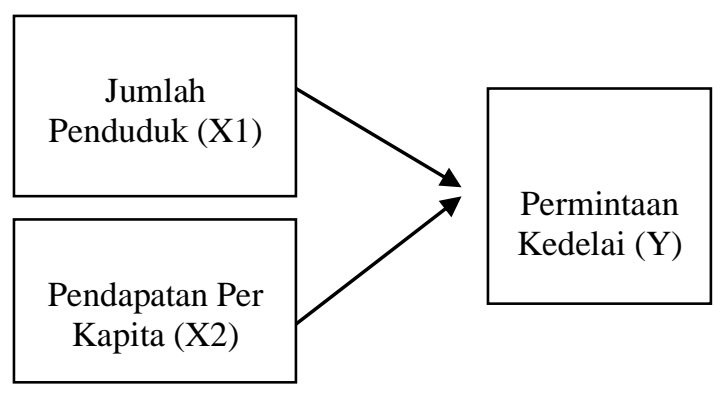

Gambar 1. Bagan Kerangka Pemikiran

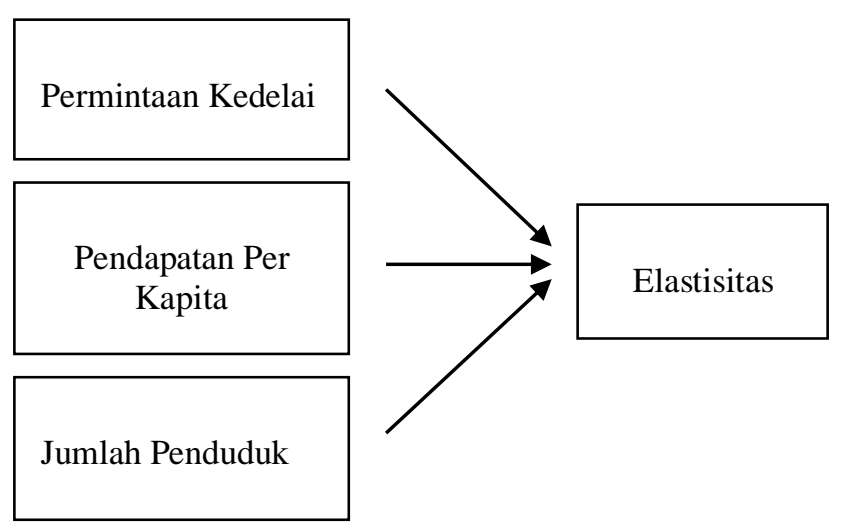

Gambar 2. Bagan Elastisitas Permintaan

\section{Hasil dan Pembahasan}

Analisis data dalam penelitian ini menggunakan SPSS 20. Sebelum melakukan uji statistik terhadap hasil olahan regresi terlebih dahulu dilakukan uji klasik sebagai dasar analisis regresi. Pengujiana sumsi klasik dimaksudkan agar estimator-estimator yang diperoleh dengan metode Ordinary Least Square (OLS) memenuhi syarat Best Linier Unbiased Estimator (BLUE). Pengujian asumsi klasik yang digunakan adalah uji 
normalitas, uji multikolinieritas, uji heteroskedasitas, dan uji autokorelasi, hal ini karena dta yang digunakan berupa data time series (Gujarat, 1997).

Tabel 1

Hasil Analisis Regresi Berganda Permintaan Kedelai Lokal di Jawa Timur, tahun 2000-2013

\begin{tabular}{lllll}
$\begin{array}{l}\text { Variabel } \\
\text { Independen }\end{array}$ & $\begin{array}{l}\text { Koefisien } \\
\text { Regresi }\end{array}$ & $\begin{array}{l}\text { t- } \\
\text { hitung }\end{array}$ & Sig & Keterangan \\
\hline Konstanta & $4.171 .227,63$ & 3,054 & 0,011 & $* *$ \\
\hline $\begin{array}{l}\text { Harga Kedelai } \\
\text { Lokal }\end{array}$ & 13,19 & 0,636 & 0,54 & $*$ \\
\hline $\begin{array}{l}\text { Harga Kedelai } \\
\text { Impor }\end{array}$ & $-2,26$ & $-0,101$ & 0,922 & $*$ \\
\hline $\begin{array}{l}\text { Pendapatan per } \\
\text { Kapita (X1) }\end{array}$ & 0,098 & 3,174 & 0,009 & $* *$ \\
\hline $\begin{array}{l}\text { Jumlah Penduduk } \\
\text { (X2) }\end{array}$ & $-0,124$ & $-2,834$ & 0,016 & $* *$ \\
\hline $\begin{array}{l}\text { Koefisien } \\
\text { Determinasi (R- }\end{array}$ & & & & \\
Square) & 0,525 & & & $* *$ \\
\hline F-hitung & 6,087 & 0,17 & & $* *$ \\
\hline Durbin Watson & 1,828 & & & $* *$ \\
\hline
\end{tabular}

\section{a. Uji R-Square}

Berdasarkan tabel diatas maka diperoleh nilai $\mathrm{R} 2=0,525$ yang berarti bahwa $52,5 \%$ variasi permintaan kedelai dapat dijelaskan oleh harga kedelai lokal, pendapatan per kapita dan jumlah penduduk. Sedangkan sisanya 47,5\% dipngaruhi oleh faktor-faktor lain diluar model dalam penelitian ini.

\section{b. Analisis Regresi Linier Berganda}

Berdasarkan hasil pengolahan data dengan SPSS 20, maka didapat persamaan model regresi sebagai berikut:

$$
\mathrm{y}=4.171 .227,630+0,98 \times 1-0,124 \times 2+e
$$

Berdasarkan tabel 1 menunjukan bahwa tingkat signifikansi dari Pendapatan per Kapita (X1) dan Jumlah Penduduk (X2) berpengaruh signifikan karena tingkat signifikansi lebih kecil dari 0,05.

c. Pengaruh Koefisien Regresi Secara Serempak Variabel Bebas Terhadap Tingkat Permintaan Kedelai Lokal di Jawa Timur (dengan uji F)

Dari regresi hubungan antara pendapatan per kapita (X1), dan jumlah penduduk (X2) terhadap permintaan kedelai (Y), maka diperoleh F-tabel sebesar 3,59 $(\alpha: 5 \%$, df1 : 2 dan df2 : 11) sedangkan F - statistik / F - hitung sebesar 6,087. Nilai F-hitung lebih besar dari $\mathrm{F}$ tabel $(6,087>3,59)$ maka hipotesis $\mathrm{H} 0$ ditolak. Ini mengartikan bahwa variabel pendapatan per kapita dan jumlah penduduk secara bersama-sama berpengaruh signifikan terhadap variabel jumlah permintaan kedelai di Jawa Timur. 


\section{d. Pengaruh Parsial Variabel Bebas Terhadap Tingkat Permintaan Sepeda Lipat (dengan uji t)}

Untuk menguji pengaruh variabel bebas secara parsial terhadap variabel terikat digunakan pengujian koefisien regresi secara parsial (uji $t$ ), yaitu dengan membandingkan t hitung dan ttabel, yang dirumuskan sebagai berikut:

1. Uji t variabel Pendapatan per $\operatorname{Kapita}(\mathrm{X} 1)$

Berdasarkan hasil data diatas diketahui bahwa $\mathrm{t}$ hitung dari variabel pendapatan per kapita adalah $(3,174)>\mathrm{t}$ tabel $(1,761)$ dimana nilai $\mathrm{t}$ hitung lebih besar dari $\mathrm{t}$ tabel dengan demikian hipotesis H0 ditolak. Jadi hipotesis yang menyatakan bahwa pendapatan per kapita mempunyai pengaruh positif terhadap permintaan kedelai, terbukti.

2. Uji t variabel Jumlah Penduduk (X2)

Diketahui bahwa t hitung dari variabel jumlah penduduk adalah $(-2,834)<\mathrm{t}$ tabel $(2,352)$ dimana nilai $t$ hitung lebih kecil dan mempunyai nilai negatif dari $t$ tabel dengan demikian hipotesis $\mathrm{H} 0$ tidak ditolak. Jadi hipotesis yang menyatakan bahwa jumlah penduduk mempunyai pengaruh positif terhadap permintaan kedelai, tidak terbukti.

\section{e. Elastisitas Permintaan}

1. Elastisitas Harga

Dari hasil analisis diketahui besarnya elastisitas harga kedelai lokal sebesar 13,19. Artinya jika harga kedelai lokal naik $1 \%$ maka permintaan kedelai akan naik sebesar 3,19, begitu juga sebaliknya. Permintaan kedelai lokal bersifat elastis karena nilai koefisiennya lebih dari 1, yang artinya setiap perubahan harga mengakibatkan perubahan lebih besar dari jumlah yg diminta.

2. Elastisitas Silang

Dari hasil analisis diketahui bahwa besarnya elastisitas silang dari harga kedelai impor adalah $-2,26$. Artinya, jika kedelai impor naik $1 \%$ maka permintaan kedelai lokal akan turun 2,26\%, begitu juga sebaliknya. Nilai elastisitas harga silang yang bertanda negatif menunjukan bahwa kedelai impor merupakan barang substitusi dari kedelai lokal

3. Elastisitas Pendapatan

Dari hasil analisis diketahui besarnya elastisitas pendapatan adalah 0,098. Ini berarti bahwa jika terjadi kenaikan pendapatan sebesar1 \% maka akan mengakibatkan bertambahnya jumlah permintaan kedelai sebesar 0,098\%, begitu juga sebaliknya. Angka elastisitas pendapatan yang lebih kecil dari satu dan bertanda positif menunjukan bahwa kedelai termasuk barang normal (inelastis).

\section{Kesimpulan}

Berdasarkan hasil penelitian dan pembahasan yang telah teruraikan sebelumnya, maka dapat ditarik kesimpulan sebagai berikut:

1. Harga kedelai lokal berpengaruh positif dan tidak signifikan terhadap jumlah permintaan kedelai 
2. Harga kedelai impor berpengaruh negatif dan tidak signifikan terhadap jumlah permintaan kedelai

3. Pendapatan per kapita berpengaruh positif dan signifikan terhadap jumlah permintaan kedelai

4. Jumlah penduduk berpengaruh terhadap jumlah permintaan kedelai

5. Elastisitas Harga, permintaan kedelai bersifat elastis karena nilai koefisiennya $>1$.

6. Elastisitas Silang, nilai elastisitas harga silang yang bertanda negatif menunjukan bahwa kedelai impor merupakan barang substitusi dari kedelai lokal.

7. Elastisitas pendapatan, angka elastisitas pendapatan yang lebih kecil dari satu dan bertanda positif menunjukan bahwa kedelai termasuk barang inelastis. 


\section{DAFTAR PUSTAKA}

Bilas, Richard A. (1994). Teori Mikro Ekonomi, Terjemahan. Jakarta: Erlangga.

Daniel, Moehar. (2001). Pengantar Ekonomi Pertanian. Jakarta: PT Bumi Aksara.

Departemen Pertanian. (2009). Outlook Komoditas Tanaman Pangan Pusat Data Infomasi Pertanian. Jakarta

Ghozali, Imam. (2006). Aplikasi Analisis Multivariate dengan Program SPSS. Jakarta

Gujarati, Damodar N. (2006). Dasar-dasar Ekonometrika Jilid 1 dan 2. Edisi Ketiga. Erlangga. Jakarta.

Gujarati, Damodar N. (2006). (United States Military Academy, West Point). Essentials of Econometrics. Third Edition. McGraw-Hill International Edition.

Imam Ghozali, (2001). Aplikasi Multivariate Dengan Program SPSS. Semarang: Universitas Diponegoro.

Mankiw, N. Gregori Euston Quah Peter Wilson. (2005). Principles Of Economics. Vol 1, Asian Edition. Salemba Empat: Jakarta.

Marshaal, Alfred. (1920). The Principles of Economics 8th Eition.

Pindyck, Robert.S dan Rubinfeld, Daniel.L. (2007). Mikroekonomi. Edisi Keenam, Jilid 1. PT. Indeks. Jakarta

Skousen, Stice. (2010). Accounting. Edisi kelima belas, Salemba Empat. Jakarta.

Samuelson, Paul A dan D. Nordhaus William. (2001). Ilmu Mikroekonomi, Terjemahan. Edisi 17. PT Media Global Edukasi. Jakarta.

Sugiarto, dkk. (2005). Ekonomi Mikro. Jakarta: Penerbit PT Gramedia Pustaka Utama

Sukirno, Sadono. (2003). Pengantar Teori Mikro Ekonomi. Jakarta: PT. Raja Grafindo Persada. 